\title{
Doctor Enrique Gurfinkel
}

Todos quienes tuvimos el honor de conocer al Dr. Enrique Gurfinkel, recibimos con gran consternación e incredulidad la noticia de su prematura partida.

Mucho más allá de sus reconocidos e incuestionables méritos profesionales que lo hacían merecedor de un prestigio y admiración irrefutables entre sus pares, el Dr. Gurfinkel fue largamente más que un Médico, un Investigador o un Docente privilegiado.

No es necesario repetir o recordar su muy extenso curriculum y sus grandes logros, conocidos por todos. Sus características e integridad como persona, le otorgaban cualidades excepcionales, muy difíciles de encontrar en nuestros tiempos. Su sencillez y modestia no se compadecían con su categoría y status profesional.

Su elegancia y distinción, no solo en su vestimenta, sino en su habitual actitud, lo habían parecer una persona de otra época, o un personaje extraído de una película o de una novela, emanando un aura especial.

Promotor de la vida sana y del deporte, nos sorprendía con su vitalidad y energía y sus levantadas a trotar de madrugada, independiente del clima y/o de las actividades científicas que lo precedían o que le esperaban.

Portador de una gran sensibilidad artística y musical, fue siempre un agrado conversar con él o intercambiar opiniones en cualquier ámbito de actualidad, independiente del tema que se quisiera abordar.

Sus inagotables buena disposición y disponibilidad cuando le solicitamos su participación o cuando requerimos su apoyo para nuestras actividades y cursos, terminaban siempre en una favorable e incondicional respuesta, la cual tenía un enorme mérito agregado, especialmente en consideración a la gran cantidad de invitaciones y solicitudes de múltiples lugares que su gran prestigio le hacía recibir.

El acudió en numerosas oportunidades a Chile a diversos eventos, cursos y Congresos organizados por la Sociedad

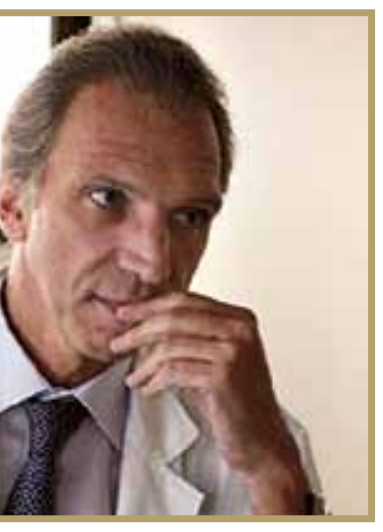

Chilena de Cardiología y cada una de sus participaciones constituyó siempre un gran e indiscutible aporte . Fue así como aceptó en tres oportunidades nuestra invitación para ser parte de las Jornadas de Otoño de Cardiología de Concepción. Después de tanto compartir, lo terminamos considerando uno de nosotros y se generó una amistad que traspasaba el ámbito profesional. Cada vez que nos llegábamos en encontrar con él en algún evento internacional, era como si hubiéramos encontrado un antiguo y gran amigo.

La última vez que nos encontramos fue muy pocos días antes de su partida, en el Congreso Interamericano de Cardiología en Cartagena de Indias, oportunidad en la cual le escuchamos una última conferencia, demostrando incluso hasta ese momento, su gran fuerza y inagotable vocación. Nunca dejó de sorprendernos con sus originales presentaciones, con el profundo contenido científico que les otorgaba y con su drástica actitud crítica cada vez que un paper, una publicación o un trial a su juicio lo ameritaban. Fue un modelo para nosotros, aprendimos mucho de él y le damos infinitas gracias por ello.

En las últimas Jornadas de Cardiología de Otoño de Concepción, le rendimos un muy sentido, emotivo y sincero homenaje. Todos quienes desconocían la triste noticia, quedaron impactados y no lo podían creer. Muchos de quienes compartimos con él no pudimos evitar emocionarnos. Esa gran emoción impidió que pudieran terminar de decirse todas las cosas de él que se habían programado.

No quisimos guardar un minuto de silencio. Por el contrario, le brindamos un gran ruidoso y cerrado aplauso.

Propusimos crear una Sesión en nuestro curso anual que llevara su nombre. La aprobación fue unánime e incuestionable.

Enrique, era lo mínimo que te merecías.

Dr.Alejandro Dapelo Aste Presidente Filial Concepción Sochicar 